\title{
Applications of Theory to Social Policy: Civic Engagement Theory
}

\author{
Richard Hoefer ${ }^{1}$
}

Published online: 1 June 2021

(c) The Author(s), under exclusive licence to Springer Nature Switzerland AG 2021

Recently I was catching up with a colleague from another university I had not seen for a long time (and really is not that all of them?). She mentioned that she had first met me at an Influencing Social Policy conference where I had given a talk about the use of theory in social policy journal articles.

She said "You know, it was your presentation about a dog park." I thought to myself, "Great! After a career full of journal articles and books, what I will be remembered for talking about a dog park" (Hoefer, 2015). ${ }^{1}$ But you know, it is okay. It shows the power of a good story to help make a point and it is an idea I truly believe in. The point was that I saw a comparative dearth of the use of theory in how social work scholars were conducting their research in social policy. I argued this was unfortunate, unnecessary, and unsustainable.

At that time, I said that while most of the submissions to the Journal of Policy Practice were well-written, they were descriptive and did not use theory as a starting point to shape the questions being asked, the variables being measured, or the relationships being tested. I argued that more use of theory was a good way to move the field forward. As the editor of The Journal of Policy Practice, I wanted those listening and later, those reading my words, to feel empowered and even compelled to dig deeper in the academic mines, searching for more valuable ores than descriptions of situations without being able to generalize or broaden the results. That is how one advances the field, I argued.

Over the past few years, I have certainly seen more work being submitted to the Journal of Policy Practice and Research that starts from theory and truly tests some elements of it. I would like to see this situation continue and grow even stronger.

\footnotetext{
${ }^{1}$ In an ironic twist, I had written these words in the article that came from that presentation: "But-and this is important, so if you only remember one thing about this article (other than that Princess died before getting her dog park), remember this - the best way to really satisfy curiosity that extends beyond the bare facts is to employ a theory" (Hoefer, 2015, p. 167).
}

Richard Hoefer

rhoefer@uta.edu

1 School of Social Work, University of Texas At Arlington, Box 19129, Arlington, TX 76019, USA 
Therefore, starting in this issue and continuing in the next few issues of this journal, I will introduce theories that I believe have great promise. In this issue I put the spotlight on Civic Engagement Model (also known as Civic Voluntarism Theory) developed by Verba et al. (1995). Many have used the theory or some variant in their work but there is much yet to learn (for good examples of scholars using the Civic Engagement Model in their research, out of the many possible, see Berklau Halvor, 2016; Ostrander, et al., 2017; Ritter, 2008, 2013; Rome \& Hoechstetter, 2010; Safadi \& Lombe, 2012; Weiss-Gal, 2016; Witt et al., 2020).

Some research questions are wonderful resources for constant tinkering, thinking, and transformations. I believe one such key question in social work policy practice is "How can we improve the level of participation in political processes by social workers?" The Civic Engagement Model is one way to help us answer the question (and others).

The Civic Engagement Model shows how political engagement and participation depend on the following:

- Resources (time, money, skills),

- Psychological engagement (political interest, political information, sense of political efficacy, partisanship, and family influences), and

- Recruitment networks (connections to people already involved).

A new program at the University of Texas Arlington called SPEAK (Social Policy Education, Advocacy, and Knowledge) started in February 2021. SPEAK is attempting to influence students in various ways, directly and indirectly, using the Civic Engagement Model to show the way to create an effective change effort. SPEAK is in the process of operationalizing the theory to impact levels of political participation among social work students at the University of Texas Arlington. This initiative is funded by Simmons Sisters Fund at Texas Women's Foundation. Here is some insight into SPEAK's operationalization of the theory to this context.

Resources such as time, money, and skills are vital for allowing political engagement. We can try to impact time and money through trainings and paid internships. We can also help link time management and value clarification exercises to "creating" more time for the things we deem important. Through trainings and engagement activities, we can develop political participation skills at the individual level. This, in turn, leads to a stronger base for political engagement in the community of social workers and allies for social justice efforts.

We can also increase the level of psychological engagement by making vital information (particularly regarding how to be active in policy-making) more available and conducting training to increase the sense of efficacy in policy-related interventions. Interest in and knowledge about political issues alone are not enough to increase participation: people must also feel their activities can be successful. Working with others helps increase information, skills, commitment, and efficacy, and will be a large part of SPEAK's work.

Finally, because of the importance of the levels of recruitment networks in increasing political participation, SPEAK will develop links to current advocacy organizations and elected officials' offices. Professional groups such as Influencing 
Social Policy, ACOSA, The Macro Social Work Group within CSWE, the Nancy A. Humphreys Institute for Political Social Work at the University of Connecticut, and others are already in collaborative relationships with SPEAK. We have conducted a baseline survey of over 100 of our students and will be able to test some of the theoretical relationships with our data. We will be writing up our results as soon as possible.

Tune in next issue for a look at another theory. For now, though, we turn to the manuscripts selected for publication in this issue.

I am extremely pleased to continue the collaboration with Influencing Social Policy (ISP), the Journal's affiliated professional organization, with the publication by the new Board Chair, Dr. Mariane Harris who discusses the beginning transformation of ISP into an anti-racist organization. As more social work organizations and schools move in this needed direction, Dr. Harris' clear description of the process will be quite helpful in showing a practical blueprint for change.

Kelly Patterson, Robert Silverman, and Chihuangji Wang show how policy can maintain racial and socioeconomic segregation despite stated goals to do otherwise. The implementation of housing policy is difficult as shown in this article. A similar theme is found in Reuben Addo and Paula Gerstenblatt's article "Housing First: A policy analysis of the Hearth Act". Their complex analysis uses a feminist ethic of care framework and finds some positives with the program, despite "inconsistencies of policy implementation."

The final two articles relate to the criminal justice system. Cherra Mathis and David Androff provide an analysis of the "crimmigration" process, which creates a convergence of criminal and immigration law. Their paper helps to explain what otherwise might be quite confusing changes in immigration law that seemingly are devoid of a rational purpose. Finally, for this issue, we can learn about the advantages of raising the age of being a "juvenile" (and thus having somewhat less criminal responsibility) up to 20 years of age. This fascinating idea is discussed by Sujeeta Menon and Susan McCarter.

With this issue we have reached the middle of our second year of publication. I am thankful to Springer Nature press, particularly Teresa Krauss; the many reviewers who provide the critical quality assessment piece to the publishing process; and the authors who submit their work to the Journal of Policy Practice and Research. Keep the manuscripts coming!

Best wishes

Dr. Rick Hoefer, Editor-in-Chief

\section{References}

Bernklau Halvor, C. (2016). Increasing social work students' political interest and efficacy. Journal of Policy Practice, 15(4), 289-313. https://doi.org/10.1080/15588742.2015.1081578

Hoefer, R. (2015). Princess wants a dog park: Using theory and evidence to understand advocacy and improve policy practice education. Journal of Policy Practice, 14(3-4), 165-170. https://doi.org/10. 1080/15588742.2015.1049066 
Ostrander, J. A., Lane, S., McClendon, J., Hayes, C., \& Smith, T. R. (2017). Collective power to create political change: increasing the political efficacy and engagement of social workers. Journal of Policy Practice, 16(3), 261-275. https://doi.org/10.1080/15588742.2016.126629

Ritter, J. (2008). A national study predicting licensed social workers' levels of political participation: the role of resources, psychological engagement, and recruitment networks. Social Work, 53(4), $347-357$.

Ritter, J. (2013). Reconceptualizing policy class as a practice class: increasing the political efficacy of Millennial students. Journal of Baccalaureate Social Work, 18(1), 1-16.

Rome, S. H., \& Hoechstetter, S. (2010). Social work and civic engagement: the political participation of professional social workers. Journal of Sociology \& Social Welfare, 37, 107-129.

Safadi, N., \& Lombe, M. (2012). Understanding the role of civic engagement and government intervention in predicting access to social services in the Global South: the case of Palestine. Journal of Policy Practice, 11(4), 273-290. https://doi.org/10.1080/15588742.2012.713828

Verba, S., Schlozman, K. L., \& Brady, H. E. (1995). Voice and equality: civic voluntarism in American politics. Harvard University Press.

Weiss-Gal, I. (2016). Social workers' policy engagement: a review of the literature. International Journal of Social Welfare, 26, 285-298.

Witt, H., Witt, R., \& Brisby, K. (2020). Does policy practice class increase social work students' planned political engagement? Journal of Policy Practice and Research, 1, 77-95. https://doi.org/10.1007/ s42972-020-00009-8 